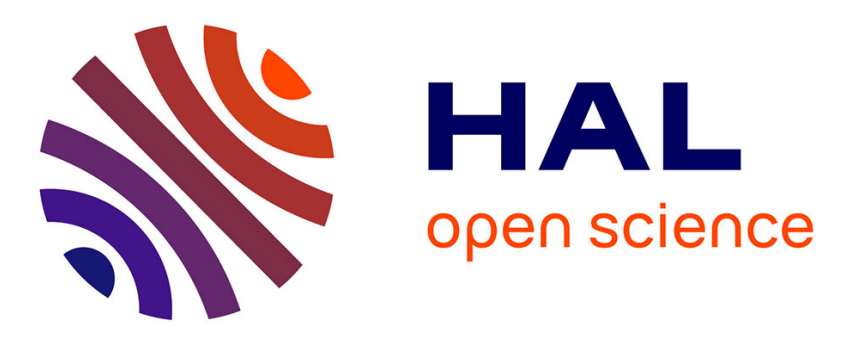

\title{
The Use of Feeding Behaviour in the Assessment of Animal Welfare
}

\author{
Birte Nielsen, Ingrid de Jong, Trevor Devries
}

\section{To cite this version:}

Birte Nielsen, Ingrid de Jong, Trevor Devries. The Use of Feeding Behaviour in the Assessment of Animal Welfare. Nutrition and the Welfare of Farm Animals, 16, Springer International Publishing, 247 p., 2016, Animal Welfare, 978-3-319-27354-9. 10.1007/978-3-319-27356-3_4 . hal-02801304

\section{HAL Id: hal-02801304 https://hal.inrae.fr/hal-02801304}

Submitted on 5 Jun 2020

HAL is a multi-disciplinary open access archive for the deposit and dissemination of scientific research documents, whether they are published or not. The documents may come from teaching and research institutions in France or abroad, or from public or private research centers.
L'archive ouverte pluridisciplinaire HAL, est destinée au dépôt et à la diffusion de documents scientifiques de niveau recherche, publiés ou non, émanant des établissements d'enseignement et de recherche français ou étrangers, des laboratoires publics ou privés. 


\title{
Chapter 4 \\ The Use of Feeding Behaviour in the Assessment of Animal Welfare
}

\author{
Birte L. Nielsen, Ingrid C. de Jong, and Trevor J. DeVries
}

\begin{abstract}
Feeding behaviour is an important aspect of animal production, as it constitutes the link between the feed provided and that which is consumed. Measures of feeding behaviour can be used as a tool with which to gauge how an animal perceives the diet offered, as well as its motivation to feed, i.e. its level of hunger. The feed intake of an animal may also depend on the presentation of the food, the previous experience of the animal with a given food, and to what extent other competing motivations affect the behaviour of the animal. In this chapter, examples from ruminants, pigs, and poultry are provided on how measures of feeding behaviour can be used to elucidate the constraints on feeding imposed by the nutritional, physical, and social environment of our production animals. For ruminants, the relationship between meal patterns and rumen fermentation is described, together with the effects of feed delivery and feeding frequency on the feeding behaviour, in particular the sorting of feed components. Further examples are provided on how competition at the feed trough results in higher feeding rates and can lead to uneven distribution of the feed between animals in a group, dependent on space availability, trough design, and partitioning. We describe how the provision of fibre may alleviate hunger and aggression in parent stock, such as gestating sows and broiler breeders that are restrictively fed. Examples are provided of how automatic feeders can be used to detect changes in the feeding patterns of individual animals, which in turn can be used in the detection of health problems. It is described how grazing ruminants show behavioural adaptability not only to changes in sward composition and height but also to hot and cold environments. Other examples include studies of feeding behaviour that have explored
\end{abstract}

\footnotetext{
B.L. Nielsen (-)

INRA, UR I 197 Neurobiologie de l'Olfaction, Université Paris-Saclay, Jouy-en-Josas, France
}

Faculty of Science and Technology. Department of Animal Science, Aarhus University. Tjele. Denmark

e-mail: birte.nielsen@jouy.inra.fr

I.C. de Jong

Livestock Research. Wageningen University and Research Centre, Wageningen,

The Netherlands

T.I. DeVries

Department of Animal Biosciences, University of Guelph. Guelph, ON. Canadia 
ways to reduce the stress experienced by piglets in connection with weaning, and how feather pecking in laying hens may be prevented by provision of roughage. Overall, the understanding of species-specific feeding behaviour and nutritional requirements is important for the assessment of animal welfare. It may help solve many feeding problems and allow animals to maximize the potential of the nutritional value of the feed provided to them.

\subsection{Introduction}

Feeding behaviour is an important aspect of animal production, as it constitutes the link between the feed and the intake. It consists of a number of different aspects, including finding the food supply, choosing the food, gaining and maintaining access to the food, as well as the amount of food eaten at any one time (meal size) and the speed of ingestion (feeding rate).

Measures of feeding behaviour can be used as a tool with which to gauge how an animal perceives the diet offered, as well as its motivation to feed, i.e. level of hunger. We expect a highly palatable feed to be eaten faster and in larger amounts than a feed with less nutritional value or with a suboptimal composition. In addition, animals that are hungry will eat faster than more satiated conspecifics (Nielsen et al. 2011). The feed intake of an animal may also depend on the presentation of the food, the previous experience of the animal with the particular food, and to what extent other competing motivations affect the behaviour of the animal. Research in rats has shown that if a given feed is first encountered when the animal is hungry, this feed is perceived as being more desirable than if the animal was satiated the first time it tasted the feed, a phenomenon known as statedependent learning (Balleine 1992; Balleine and Dickinson 1998).

Animals on the farm usually feed in groups, involving competition between group members for access to the feed as well as social facilitation, where an animal begins to feed because it sees another animal feeding. The latter does not necessarily affect intake in the long term, but may add to the level of competition already present, if several group members attempt to eat simultaneously from limited trough space. Differences between animals in their feeding behaviour may reflect different levels of stress when feeding (Nielsen 1999a, b, 2004), and changes within an animal over time may also relate to changes in its health (Bach et al. 2007; Goldhawk et al. 2009; Desnoyers et al. 2011).

It is often difficult to identify feeding problems amongst group-housed animals. Individual feeding behaviour may be overlooked in farming environments where feed intake is measured at group level. However, the increased accessibility of technologies such as transponders, which automatically register individual visits to the food trough, will enable automatic, real-time, within- and between-animal comparisons of feeding behaviour, thus allowing producers to prioritize inspection of those animals, which show signs of aberrant feeding within a group as flagged by such systems (Shabi et al. 2005; Borderas et al. 2009).

In $\mathrm{tl}$

conside ruminar with in example constrai of the ar feeding animal. understa taking in more mc

The $\mathrm{n}$ of the an economis tions are behaviou worth ket sive to in on moder

\section{$4.2 \mathrm{Rl}$} Sy

\section{$4.2 .1 \quad I$}

Under natı 9 h/day (F smaller me early mon modified $\mathrm{ft}_{\mathrm{t}}$ dairy cattl (DM) intak et al. 2003 meals mort rumen $\mathrm{pH}$ (SARA) (K increased ri of this pH c concentratic spend less c Salivary sec 


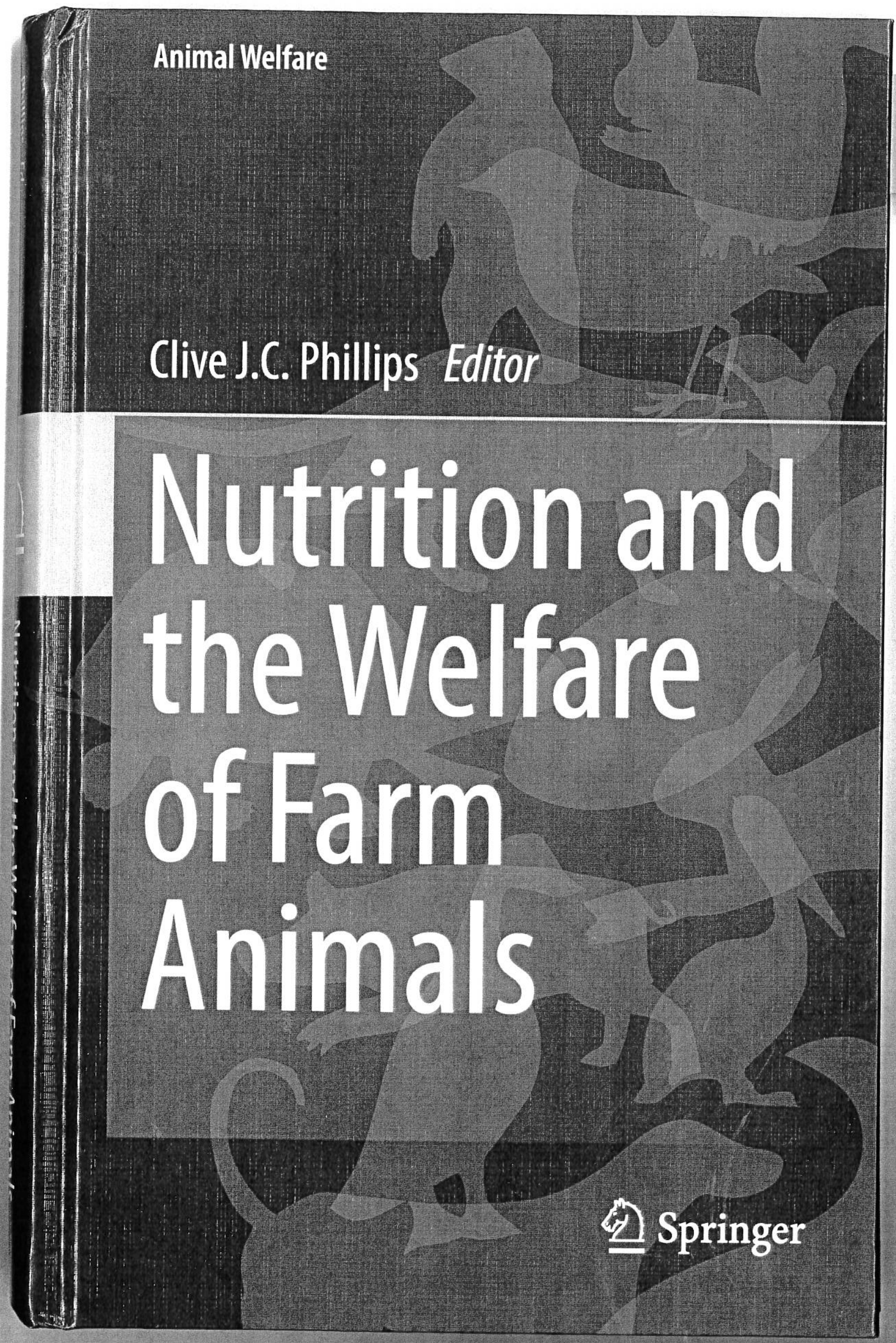




\title{
Animal Welfare
}

\author{
Volume 16
}

\section{Series Editor}

Professor Clive Phillips

Foundation Chair of Animal Welfare

Centre for Animal Welfare and Ethics

School of Veterinary Science

University of Queensland

Gatton 4343, QLD

Australia 

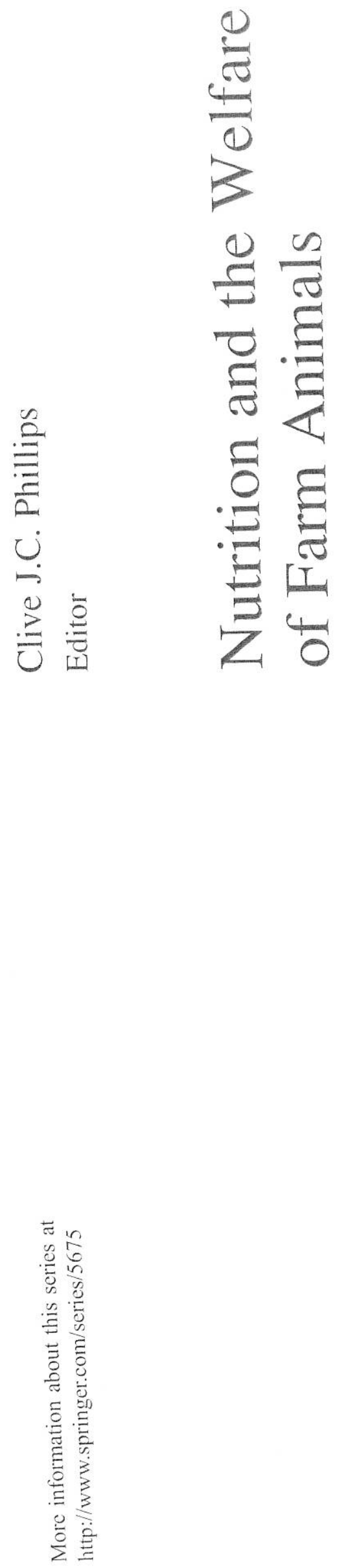


\section{Editor}

Clive J.C. Phillips

Centre for Animal Welfare and Ethics

University of Queensland

Gatton, Australia

ISSN $1572-7408$

Animal Welfare

ISBN 978-3-319-27354-9

ISBN 978-3-319-27356-3 (eBook)

DOI 10.1007/978-3-319-27356-3

\section{Library of Congress Control Number: 2016933444}

C Springer International Publishing Switzerland 2016

This work is subject to copyright. All rights are reserved by the Publisher, whether the whole or part of the material is concerned, specifically the rights of translation, reprinting, reuse of illustrations, recitation, broadcasting, reproduction on microfilms or in any other physical way, and transmission or information storage and retrieval, electronic adaptation, computer software, or by similar or dissimilar methodology now known or hereafter developed.

The use of general descriptive names, registered names, trademarks, service marks, etc. in this publication does not imply, even in the absence of a specific statement, that such names are exempt from the relevant protective laws and regulations and therefore free for general use.

The publisher, the authors and the editors are safe to assume that the advice and information in this book are believed to be true and accurate at the date of publication. Neither the publisher nor the authors or the editors give a warranty, express or implied, with respect to the material contained herein or for any errors or omissions that may have been made.

\section{Printed on acid-free paper}

This Springer imprint is published by Springer Nature

The registered company is Springer International Publishing AG Switzerland 